\title{
ЕФЕКТИВНІСТЬ ЕЛЕМЕНТІВ БІОЛОГІЗАЦІЇ СИСТЕМИ ЗАХИСТУ ПШЕНИЦІ ОЗИМОЇ, ЯЧМЕНЮ ОЗИМОГО ТА СОЇ В УМОВАХ ЗРОШЕННЯ ПІВДНЯ УКРАЇНИ
}

\author{
Заєць С. О., Рудік О. Л.
}

\section{ВСТУП}

Для промислового аграрного виробництва застосування засобів захисту рослин є невід'ємним складником сучасних технологій вирощування практично всіх сільськогосподарських культур. Запровадження системи інтенсивного сільського господарства зумовило значне збільшення продуктивності, однак утрати врожаю від шкідливих організмів при цьому тільки зросли. За даними, представленими Міжнародною конвенцією по карантину та захисту рослин, шкідники та хвороби щорічно спричиняють втрати до $40 \%$ світового врожаю сільськогосподарських культур та зумовлюють супутні втрати у сфері торгівлі сільськогосподарською продукцією, які перевищують 220 млрд доларів ${ }^{1} .3$ економічного погляду обгрунтований системний захист рослин більш ефективний, ніж усунення відповідних негативних наслідків, а тому він активно реалізується шляхом застосування саме сучасних хімічних препаратів ${ }^{2}$.

Однак поширення системи інтенсивного рослинництва потенційно небезпечне численними побічними явищами: деградацією грунту, забрудненням водойм та агроценозів, що становить велику небезпеку як нині, так і в майбутньому. Численними науковими дослідженнями доведено, що внаслідок циркуляції у грунті, повітряному та водному середовищі перенесення живими організмами по ланцюгах живлення хімічні препарати та продукти їх розпаду поширюються навіть на суміжні природні ландшафти і масово попадають у продукти харчування 3 відповідними негативними наслідками․․ I хоча наукою та аграрною практикою напрацьовано значну кількість заходів регулювання присутності шкодочинних організмів різного ступеня ефективності, у сучасних інтегрованих системах захисту рослин домінуючим залишається хімічний метод. За прогнозами, ця тенденція буде зберігатися у майбутньому, оскільки науково обгрунтоване застосування пестицидів порівняно з іншими способами захисту забезпечує високу технічну й економічну ефективність. Із метою захисту здоров'я

\footnotetext{
${ }^{1}$ URL : http://www.fao.org/news/story/ru/item/1253731/icode/.

2 Корнійчук М.С. Захист польових культур від шкідників і хвороб за технологій органічного виробництва. Збірник наукових працьь Національного наукового иентру «Інститут землеробства НАAН». 2014. Вип. 1-2. С. 98-110.

${ }^{3}$ Бровдій В.М. Біологічний захист рослин : навчальний посібник. Київ : Світ, 2004. 352 с.
} 
населення та навколишнього природного середовища в економічно розвинених країнах дуже суворим $\epsilon$ регулювання ринку препаратів захисту рослин ${ }^{4}$. Для подолання зазначених негативних процесів почали все більше застосовувати засоби біологічного контролю, які включають використання природних об’єктів, таких як штами мікроорганізмів та мікробні метаболіти, котрі стають альтернативою хімічним пестицидам та добривам. Значними перевагами мікробіологічних препаратів як об'єктів живої природи є здатність, за наявності відповідних умов, розмножуватися та підтримувати популяцію в агрофітоценозах, а також відсутність токсичного впливу на організм людини 5 .

На даному етапі важливими науково-практичними проблемами $\epsilon$ глибоке вивчення біологічних процесів, пов'язаних із вирощуванням культур за сучасними технологіями, дослідження популяційної динаміки шкідливих і корисних організмів, удосконалення систем захисту шляхом використання біологічних засобів, що надає можливість скоротити застосування пестицидів i суттєво зменшити негативний вплив на навколишнє середовище та поліпшити якість отримуваної продукції.

\section{1. Методологічні підходи та умови запровадження елементів біологізації системи захисту озимих зернових культур і сої}

Зважаючи на складність та системний характер проблеми запровадження заходів біологізації сучасних технологій, перспективним напрямом уважається саме раціональне поєднання максимального використання мікроорганізмів, що характеризуються селективним впливом, 3 іншими сучасними поліфункціональними методами, які застосовуються в сучасному промисловому аграрному вирощуванні ${ }^{6}$.

Зональною особливістю Сухостепової природно-сільськогосподарської зони України, яка означена як зона ризикованого землеробства, $\epsilon$ значні коливання метеорологічних показників, які періодично суттєво виходять за межі оптимальних параметрів. Негативний вплив високих температур, часті і тривалі бездощові періоди та посухи зумовлюють проблеми проведення сівби озимих культур в оптимальні календарні терміни. Отже, виникають проблеми розроблення адаптивних технологій вирощування озимих зернових культур, які передбачають фактор часу та відповідне коригування системи захисту із застосуванням

\footnotetext{
${ }^{4}$ Василенко Л. Удосконалення державної політики у сфері обігу пестицидів. Економічний дискурс. 2018. Вип. 2 С. 25-31. DOI : 10.36742/2410-0919.

5 Вожегова А.А., Кривенко А.І. Вплив біопрепаратів на продуктивність пшениці озимої та економічно-енергетичну ефективність технології ії вирощування в умовах Півдня України. Вісник аграрної науки Причорномор'я. 2019. № 1. С. 39-46. DOI : 10.31521/2313-092X/2019-1(101)-6.

Буцяк А.А. Мікроорганізми як альтернатива пестицидам у виробництві екологічно безпечної продукції рослинництва. Науковий вісник Львівського наиіонального університету ветеринарної медицини та біотехнологій ім. Гжииького. 2013. T. 15. № 1(4). С. 30-34. URL : http://nbuv.gov.ua/ UJRN/nvlnu_2013_15_1(4)_8.
} 
заходів біологізації. В умовах інтенсивного сільськогосподарського виробництва Півдня України такі дослідження проводяться Інститутом зрошуваного землеробства НААН. Метою представлених досліджень $\epsilon$ визначення ефективності застосування заходів хімічного та біологічного захисту окремих польових культур в умовах зрошення та пошук систем, що дають змогу досягти високого рівня врожайності за поліпшення якості продукції та зменшення негативного впливу хімічних речовин на навколишнє середовище відповідно до здійснюваних кліматичних змін.

Польові досліди проводилися протягом 2017-2019 рр. на дослідному полі Інституту зрошуваного землеробства НААН. Умови місця дослідження $є$ типовими для Сухостепової природно-сільськогосподарської зони України. Грунт дослідної ділянки темно-каштановий, середньосуглинковий, уміст гумусу в орному шарі грунту становить $2,6 \%$, уміст азоту i фосфору - низький, калію - високий. Масив розташований у зоні Інгулецької зрошувальної системи. У досліді в короткоротаційній сівозміні під час вирощування культур застосовували водозберігаючі варіанти рекомендованого режиму зрошення. Сівозміною передбачено таке чергування культур: 1. соя; 2. пшениця озима, ячмінь озимий; 3. ріпак озимий; 4. пшениця озима; 5. кукурудза. Дослідження проводили із застосуванням адаптованих до умов вирощування сортів пшениці та сої селекції Інституту зрошуваного землеробства.

Сорт пшениці м'якої озимої Анатолія посухостійкий, із зимостійкістю вище середнього, стійкий до вилягання та ураження хворобами, відрізняється інтенсивним кущенням та не осипається. Урожайність по пару становить $5 \mathrm{~T} /$ га, а за зрошення - понад 9,0 т/га. Належить до цінних пшениць.

Сорт пшениці м'якої озимої Бургунка середньорослий, посухостійкий, із зимостійкістю вище середнього, стійкий до вилягання та ураження хворобами, відрізняється інтенсивним кущенням. Урожайність по пару становить 5 т/га, а за зрошення - понад 10,0 т/га. Належить до сильних пшениць.

Сорт сої Діона дуже скоростиглий (80-85 діб), характеризується підвищеною адаптивною здатністю до несприятливих умов, $\epsilon$ Національним стандартом. Урожайність зерна в умовах зрошення в основних посівах становить 2,5-3,2 т/га.

Середньостиглий сорт Даная (115-118 діб) характеризується підвищеною стійкістю до вилягання й розтріскування бобів та стійкістю до ураження переноспорозом. Урожайність в умовах зрошення становить 3,7-4,0 т/га.

Середньостиглий сорт Святогор (120-127 діб) стійкий до вилягання, розтріскування бобів та ураження хворобами. Урожайність в основних посівах в умовах зрошення становить 4,0-4,6 т/га. 
Сорт ячменю Селекційно-генетичного інституту - Національний центр насіннєзнавства та сортовивчення зернового використання Академічний. Сорт типово озимий, високоінтенсивного типу, середньо ранньостиглий, характеризується високою зимостійкістю, посухостійкістю та стійкістю до вилягання й осипання. Сорт характеризується генетично зумовленою стійкістю до різних видів сажки, проявляє чутливість до ринхоспоріозу та смугастого гельмінтоспоріозу. Потенціал урожайності становить $10,5 \mathrm{т} /$ га.

Сорт ячменю Селекційно-генетичного інституту - Національний центр насіннєзнавства та сортовивчення зернового використання Достойний. Сорт озимий-дворучка із підвищеною адаптивною здатністю до умов південних регіонів України. Добре кущиться за пізніх сходів восени та ранньою весною, скоростиглий, характеризується середньою зимостійкістю й стійкістю до вилягання та осипання, середньою стійкістю до хвороб. Потенціал урожайності становить 10,0 т/га.

Біологічна система захисту рослин базувалася на використанні препаратів «Псевдобактерін 2», «Бактофіт», «Бітоксибацилін-БТУ», «Лепідоцид-БТУ».

«Псевдобактерін 2» - біологічний фунгіцид проти збудників грибкових та бактеріальних хвороб із рістстимулюючим ефектом. Біопрепарат сертифікований згідно зі стандартами Європейського Союзу для виробництва органічної продукції.

Він володіє токсичністю проти широкого спектру збудників грибкових та бактеріальних хвороб рослин (Fusarium, Helminthosporium, Pseudocercosporella, Pythium, Erysiphe, Septoria, Pyrenophora, Puccinia, Pseudomonas, Xanthomonas, Rhizoctonia, Cladosporium, Erysiphe, Cercospora), забезпечуючи активний захист та профілактику. У його склад входять живі клітини ризобактерій роду Pseudomonas auerofaciens титр $2 \times 10^{9} \mathrm{KУO} / \mathrm{cm}^{3}$ та продукти їх метаболізму: сідеросфори, піолютеорин, индулил-3-уксусна кислота та гібереліноподібні сполуки та ферменти. Препарат призначений для захисту зернових-колосових, деяких технічних і овочевих та інших видів сільськогосподарських культур, також він поліпшує фосфорне живлення рослин.

«Бактофіт» - біологічний фунгіцид широкого спектру дії, призначений для захисту зернових-колосових, овочевих культур, кукурудзи, соняшника від грибних і бактеріальних захворювань (Fusarium, Bipolaris, Ophiobolus, Erysiphe, Septoria, Pyrenophora, Puccinia, Botrytis spp., Pseudomonas, Xanthomonas ma інші). У його складі спори та живі клітини бактерії Bacillus subtilisma, Bacillus amyloliquefaciens - титр $2 \times 10^{9} \mathrm{KУO} / \mathrm{cm}^{3}$ і продукти їх метаболізму. Препарат стимулює ріст і розвиток рослин, прискорює біологічну активність та посилює азотний поживний режим. 
«Бітоксибацилін-БТУ®-р» - біоінсектицид для захисту зернових, бобових, технічних та овочевих культур від комах-шкідників та кліщів. До його складу входять життєздатні клітини бактерії Bacillus thuringiensis, ендоспори - титр $1 \times 10^{9} \mathrm{KУO} / \mathrm{cm}^{3}$ та біологічно активні продукти життєдіяльності бактерії: білкові кристали (ендотоксин) і термостабільний екзотоксин. Рекомендується застосовувати для знищення личинок різного віку та імаго колорадського жука, попелиць, кліщів та гусениць лускокрилих комах-шкідників у період вегетації. Препарат, попадаючи в організм комах зі з’їденим листям, викликає параліч кишківника, унаслідок чого шкідники гинуть.

«Лепідоцид-БТУ®-р» - біоінсектицид для захисту зернових, бобових, овочевих та інших рослин від лускокрилих комах. Являє собою життездатні клітини бактерії Bacillus thuringiensis var. kurstaki, ендоспори - титр $1 \times 10^{9} \mathrm{KУO} / \mathrm{cm}^{3}$ та біологічно активні продукти життєдіяльності бактерій - ендотоксини. Препарат кишкової дії має тривалість захисту до 14 днів, не викликає звикання у комах-шкідників.

Погодні умови років досліджень суттєво різнилися між собою. Найбільш сприятливими для отримання сходів озимих культур були умови 2016 p. Температурний режим у роки досліджень був сприятливим для осінньо-зимового періоду росту і розвитку посівів озимих культур (рис. 1).

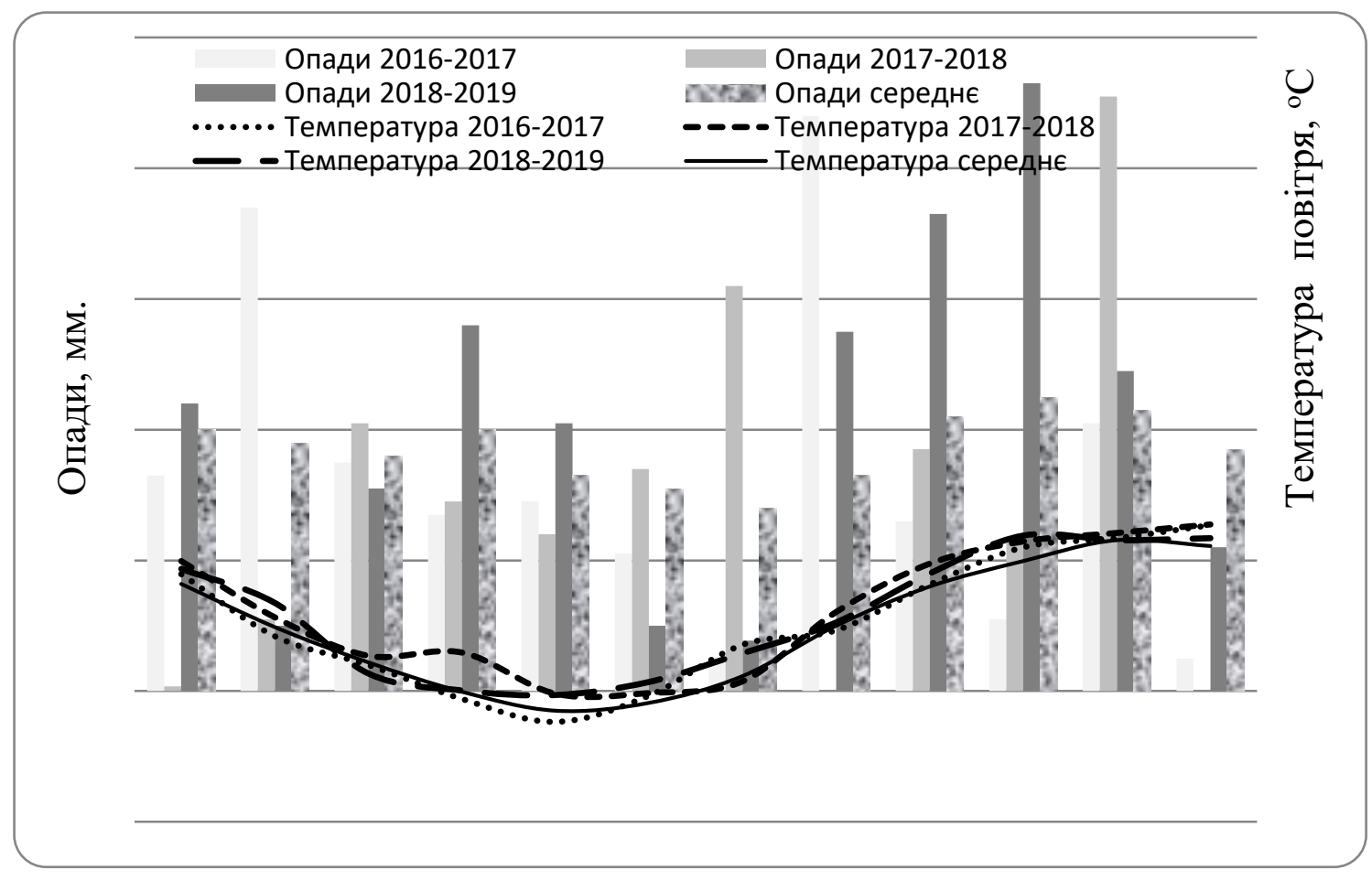

Рис. 1. Температура повітря та надходження опадів у роки дослідження 
У весняно-літній період, із березня по червень, надходження опадів у 2017 та 2018 рр. становило 87,4\% та 82,4\% від багаторічних значень, тоді як у 2019 p. - 154,4\%. У період із травня по серпень надходження опадів становило відповідно 49,7\%, 90,4\% та $141,9 \%$. Таким чином, умови 2019 р. були аномально вологими для озимих зернових культур та сої. При цьому температурний режим у період вегетації озимих та пізніх ярих культур значно перевищував середні багаторічні значення. У досліді застосовано зональні технології вирощування культур за зрошення.

\section{2. Агробіологічні аспекти біологізації системи}

захисту пшениці озимої та ячменю озимого в умовах зрошення

Пшеницю озиму в зоні Сухого Степу пошкоджують багато шкідливих організмів, серед яких - хлібні жуки, попелиці, трипси, клопи шкідлива черепашка, септоріоз, борошниста роса, гельмінтоспоріоз та інші плямистості, бура листкова іржа, кореневі гнилі (фузаріозна, гельмінтоспоріозна, церкоспорельозна) ${ }^{7}$. Зважаючи на харчове використання та великі обсяги вирощування заходи біологізації, використання біоінсектицидів та біофунгіцидів у технології вирощування культури має велике виробниче й екологічне значення.

Дослідження проводили на двох сортах пшениці озимої м'якої Анатолія та Бургунка (фактор А) за оптимального й пізнього для даної зони термінів сівби - 20 вересня та 20 жовтня (фактор В). Система захисту (фактор С) передбачала три градації: контроль - на фоні протруювання насіння Кінто Дуо $(2,0$ л/т) + гербіцид «Гроділ Максі» $(0,11$ л/га) без внесення фунгіцидів та інсектицидів; біологічний - на вказаному фоні застосування «Псевдобактерін 2» (1,0 л/га) (BВCH 30) «Бактофіт» (3 л/га) + біоінсектицид «Бітоксибацилін БТУ» (10 л/га) (BBCH 49); хімічний - на вказаному фоні внесення фунгіциду «Капало» $(1,0$ л/га) (ВВСН 30) + фунгіциду «Адексар Плюс» $(1,0$ л/га $)+$ інсектициду «Коннект» (0,5 л/га) (ВВСН 49).

Обробка насіння проводилася за два дні до сівби, що забезпечувало захист посівів від розвитку грибних хвороб в осінній період.

Надходження опадів, динаміка температур та умови перезимівлі визначали специфічність поширення шкідників та хвороб. Так, за результатами 2019 р. на варіантах пізніх строків сівби у фазу молочновоскової стиглості спостерігалося поширення борошнистої роси та бурої іржі, тоді як ураження листя септоріозом було меншим. Проявлялися $\mathrm{i}$ генетично зумовлені ознаки толерантності. Сорт пшениці озимої Бургунка проявляв вищу стійкість до бурої іржі, тоді як Анатолія - до

\footnotetext{
Антипова Л.К. Шкідливі об’єкти в посівах пшениці озимої. Вісник аграрної науки Причорномор'я. 2013. Т. 1. Вип. 4. С. 95-102. DOI : 10.31521/2313-092X. 
септоріозу й борошнистої роси. За сприятливих умов для поширення шкідливих організмів технічна ефективність системи заходів біологічного захисту становила $11,8 \%$ проти септоріозу, $49,9 \%$ відносно борошнистої роси та 19,3\% - щодо бурої іржі. Ефективність системи хімічного захисту за таких умов для зазначених об'єктів була вищою і відповідно становила 59,3\% 87,2\% та 92,2\%.

У роки досліджень серед фітофагів пшениці озимої найбільшого поширення досягала популяція клопа-черепашки (Eurygaster integriceps Put.), злакової попелиці (Sitobion avenae F.), пшеничного трипсу (Haplothrips tritici Kurd.), п’явиці червоногрудої (Oulema melanopus L.) та жука-кузьки (Anisoplia austriaca Hrbst.). За результатами спостережень у сприятливих для морфогенезу пшениці озимої умов пізні строки сівби зумовлювали зростання чисельності злакової попелиці, пшеничного трипсу та хлібного жука, однак зменшували популяцію клопачерепашки. Застосування інсектициду «Коннект» $(0,5$ л/га) забезпечувало високий та стійкий технічний ефект обробітку, тоді як ефективність препарату «Бітоксибацилін-БТУ» (10 л/га) суттєво залежала від дати обробітку, що було зумовлено термінами сівби культури. Високою, у середньому в межах 91,7-97,8\%, була технічна ефективність елементів хімічного захисту проти злакової попелиці, пшеничного трипсу та п'явиці червоногрудої, тоді як ефективність проти хлібного жука становила лише $51 \%$. Технічна ефективність застосування біофунгіциду «Бітоксибацилін-БТУ» (10 л/га) коливалася в межах 17,4-35,2\%.

Зменшення пошкоджень та ураження культури позитивно впливає на формування наземної маси, елементів структури та величини врожаю культури. За біологічної та хімічної системи захисту незалежно від термінів сівби сорти формували на 4,8\% та 9,9\% більше продуктивних стебел. За масою насіння одного колоса в роки, несприятливі для формування наземної маси та поширення захворювань, спостерігалися переваги варіантів хімічного та біологічного захисту. Проте у середньому різниця між варіантами була недостовірною. У сприятливому для поширення шкідливих організмів 2019 р. на варіантах біологічного та хімічного захисту було встановлено достовірно більшу масу 1000 насінин. Зменшення кількості зерен у колосі, що спостерігалося при цьому, було зумовлене зростанням на $10,9 \%$ та $18,8 \%$ кількості продуктивних пагонів (табл. 1).

За кількістю продуктивних стебел сорт Анатолія проявляв більш виражену реакцію на досліджувані системи захисту порівняно із сортом Бургунка, тоді як у останнього відбувалося суттєвіше збільшення маси 1000 зерен. 
Таблиця 1

Показники структури врожаю сортів пшениці озимої залежно від строків сівби і захисту рослин (середнс за 2017-2019 рр.)

\begin{tabular}{|c|c|c|c|c|}
\hline \multirow[b]{2}{*}{$\begin{array}{c}\text { Строки сівби } \\
\text { (фактор В) }\end{array}$} & \multirow[b]{2}{*}{$\begin{array}{c}\text { Захист рослин } \\
\text { (фактор С) }\end{array}$} & \multicolumn{3}{|c|}{ Показники } \\
\hline & & $\begin{array}{c}\text { кількість } \\
\text { продуктивних } \\
\text { стебел, шт./м² }\end{array}$ & $\begin{array}{c}\text { маса зерен } \\
\text { одного } \\
\text { колоса, шт. }\end{array}$ & $\begin{array}{c}\text { маса } \\
1000 \\
\text { зерен, г }\end{array}$ \\
\hline \multicolumn{5}{|c|}{ сорт Анатолія (фактор А) } \\
\hline \multirow{3}{*}{ 20.IX } & Контроль & 603 & 1,18 & 39,7 \\
\hline & Біологічний & 643 & 1,16 & 40,2 \\
\hline & Хімічний & 661 & 1,17 & 41,3 \\
\hline \multirow{3}{*}{ 20.X } & Контроль & 544 & 1,07 & 41,3 \\
\hline & Біологічний & 564 & 1,12 & 41,4 \\
\hline & Хімічний & 620 & 1,07 & 42,1 \\
\hline \multicolumn{5}{|c|}{ сорт Бургунка (фактор А) } \\
\hline \multirow{3}{*}{ 20.IX } & Контроль & 609 & 1,11 & 38,3 \\
\hline & Біологічний & 640 & 1,10 & 39,1 \\
\hline & Хімічний & 664 & 1,10 & 40,1 \\
\hline \multirow{3}{*}{$20 . X$} & Контроль & 556 & 1,10 & 37,7 \\
\hline & Біологічний & 579 & 1,11 & 39,2 \\
\hline & Хімічний & 599 & 1,10 & 40,1 \\
\hline
\end{tabular}

Система, що передбачала використання хімічних препаратів, проявила більш вагомий вплив на формування елементів структури врожаю пшениці озимої порівняно з біологічними та контролем, що сильніше проявлялося в роки, сприятливі для поширення шкідливих організмів. Установлено достовірне зростання врожайності пшениці озимої порівняно $з$ контролем (табл. 2).

Найвищу врожайність у середньому по кожному досліджуваному фактору було встановлено в 2017 р., тоді як найнижчу - у сприятливому для поширення шкідників та хвороб 2019 р. Представлені сорти проявляли індивідуальну реакцію на досліджувані системи захисту. Так, за сівби сорту Анатолія в пізні строки було встановлене суттєвіше підвищення врожайності зерна, ніж за сівби 20.09, тоді як у сорту Бургунка вищою була прибавка від систем захисту за висіву в ранні терміни (20.09).

Вищий за абсолютними значеннями врожай зерна пшениці було отримано за системи захисту посівів із використанням хімічних препаратів. Так, якщо прибавка зерна від заходів біологічного захисту становила 0,34 т/га, то від хімічного - 0,63 т/га, проте достовірною була різниця між цими варіантами лише в окремі роки та в окремих варіантах 
досліду. Це свідчить про необхідність розроблення на основі біологічних препаратів адаптивних інтегрованих систем захисту пшениці озимої.

Таблиця 2

Урожайність сортів пшениці озимої залежно від строку сівби і системи захисту рослин, т/га

\begin{tabular}{|c|c|c|c|c|c|}
\hline \multirow{2}{*}{$\begin{array}{c}\text { Строки сівби } \\
\text { (фактор В) }\end{array}$} & \multirow{2}{*}{$\begin{array}{c}\text { Захист рослин } \\
\text { (фактор С) }\end{array}$} & \multicolumn{3}{|c|}{ Роки досліджень } & \multirow{2}{*}{ Середнє } \\
\hline & & 2017 & 2018 & 2019 & \\
\hline \multicolumn{6}{|c|}{ сорт Анатолія (фактор А) } \\
\hline \multirow{3}{*}{ 20.IX } & Контроль & 7,83 & 6,95 & 6,33 & 7,04 \\
\hline & Біологічний & 8,16 & 7,33 & 6,69 & 7,39 \\
\hline & Хімічний & 8,43 & 7,57 & 7,00 & 7,67 \\
\hline \multirow{3}{*}{ 20.X } & Контроль & 6,23 & 6,26 & 5,09 & 5,86 \\
\hline & Біологічний & 6,66 & 6,52 & 5,64 & 6,27 \\
\hline & Хімічний & 7,00 & 6,86 & 6,04 & 6,63 \\
\hline \multicolumn{6}{|c|}{ сорт Бургунка } \\
\hline \multirow{3}{*}{ 20.IX } & Контроль & 7,38 & 6,89 & 5,88 & 6,72 \\
\hline & Біологічний & 7,78 & 7,20 & 6,15 & 7,04 \\
\hline & Хімічний & 7,99 & 7,65 & 6,42 & 7,35 \\
\hline \multirow{3}{*}{ 20.X } & Контроль & 5,92 & 6,96 & 5,64 & 6,17 \\
\hline & Біологічний & 6,24 & 7,14 & 5,89 & 6,42 \\
\hline & Хімічний & 6,58 & 7,30 & 6,06 & 6,65 \\
\hline \multicolumn{2}{|c|}{$\begin{array}{c}\mathrm{HIP}_{05} \text {, для часткових } \\
\text { відмінностей: A }\end{array}$} & 0,57 & 0,56 & 0,17 & \\
\hline \multicolumn{2}{|c|}{$\mathrm{B}$} & 0,61 & 0,28 & 0,30 & \\
\hline \multicolumn{2}{|c|}{$\mathrm{C}$} & 0,37 & 0,30 & 0,24 & \\
\hline
\end{tabular}

У середньому за сівбі в ранні строки (20.09) найвищий урожай зерна був сформований сортом Анатолія за системи захисту з використанням хімічних препаратів - 7,67 т/га та 7,39 т/га - за застосування препаратів біологічного походження. За пізніх строків сівби (20.10) сорти Анатолія і Бургунка формували врожайність зерна 6,63-6,65 т/га за застосування системи хімічного захисту та 6,27-6,42 т/га - за біологічного захисту посівів.

Високий урожай якісного зерна ячменю озимого неможливо отримати без утримання чистих посівів. Основоположними умовами, що дають змогу поліпшити фітосанітарний стан посівів, $\epsilon$ впровадження у виробництво сортів із генетично зумовленою стійкістю до поширених у зоні хвороб та застосування обгрунтованих систем на основі сучасних хімічних та біологічних препаратів захисту рослин.

У дослідженнях використовували сорти ячменю (фактор А) Академічний (середньостиглий, типово озимий) і Достойний (ранньо- 
стиглий, дворучка). Ячмінь висівали в два строки (фактор В): 10.10, який $\epsilon$ рекомендованим для даної зони, та 20.10, який є пізнім. Дослідження проводилися за трьох систем захисту (фактор С) на фоні протруєння насіння препаратом «Кінто Дуо, к.с.» (2 л/т) і внесенні гербіциду «Гроділ Максі OD, о.д.» $(0,11$ л/га). За хімічної системи захисту сортів ячменю озимого застосовували фунгіциди «Солігор 425 ЕС, к.е.» $(0,8$ л/га), (ВВСН 30) та фунгіцид «Адексар Плюс, к.е.» $(1,0$ л/га) i інсектицид «Коннект, к.с.» $(0,5$ л/га), (ВВСН 49). За біологічних заходів захисту посівів ячменю застосовували біофунгіцид «Псевдобактеріном 2» (2 л/га), (ВВСН 30), а також біофунгіцид «Бактофіт» $(2,5$ л/га) i біоінсектицид «Бітоксибацилін-БТУ» (10 л/га), (ВВСН 49).

Весняне застосування гербіциду «Гроділ Максі» $(0,11$ л/га) на всіх дослідних ділянках забезпечило на час обстеження ефективності заходу пригнічений стан або повну загибель наявних бур'янів, таких як кучерявець Coфiї (Descurania Sophia L.), грицики звичайні (Capsella bursa-pastoris L.), лобода біла (Chenopodium album L.). На момент збирання культури забур'яненість була низькою, у посівах відзначено присутність рослин березки польової (Convolvulus arvensis L.).

Технічна ефективність дії проти сітчастої плямистості біологічних препаратів «Псевдобактерін 2» $(1,0$ л/га) та «Бактофіт» $(2,5$ л/га) в умовах сприятливого для поширення захворювань 2019 р. в середньому на сортах та строках сівби становила $34,4 \%$, а хімічних препаратів «Солігор» $(0,8$ л/га) перед трубкуванням та «Адексар Плюс» $(1,0$ л/га) на початку колосіння - 80,2\%. При цьому у сорту Достойний технічна ефективність системи хімічного захисту була вищою - 90,5\% порівняно iз сортом Академічний - 70,0\%, тоді як біологічного, навпаки, відповідно 19,3\% та 49,6\%.

У системі інсектицидного захисту також була вищою технічна ефективність хімічних препаратів: проти п'явиці червоногрудої - $100 \%$, злакової попелиці - 70,8\%, клопа-черепашки - 81,8\%, пшеничного трипсу $-77,7 \%$. Ефективність застосування на початку колосіння препарату «Бітоксибацилін-БТУ» (10 л/га) становила проти п’явиці червоногрудої $63,4 \%$ та злакової попелиці - 40,6\%, клопа-черепашки $30,2 \%$ та найменшою - щодо пшеничного трипсу - $16,7 \%$. Вищою була технічна ефективність систем захисту за використання сорту Достойний та проведення сівби в оптимальні терміни.

Несхожі за екотипом сорти ячменю, відповідно до тривалості осінньої вегетації, проявляли різну реакцію на зміну строку сівби. Типово озимий сорт Академічний на умови пізнього припинення вегетації реагував збільшенням кількості продуктивних пагонів. Сорт-дворучка Достойний незалежно від погодних умов за зміщення строку сівби стабільно зменшував їх кількість (табл. 3). 
Таблиця 3

Показники структури врожаю сортів ячменю залежно від строків сівби і захисту рослин (середнс за 2017-2019 рр.)

\begin{tabular}{|c|l|c|c|c|}
\hline \multirow{2}{*}{$\begin{array}{c}\text { Строки } \\
\text { сівби } \\
\text { (фактор В) }\end{array}$} & $\begin{array}{c}\text { Захист } \\
\text { рослин } \\
\text { (фактор С) }\end{array}$ & $\begin{array}{c}\text { кількість } \\
\text { продуктивних } \\
\text { стебел, шт./m }\end{array}$ & $\begin{array}{c}\text { маса зерен } \\
\text { одного колоса, } \\
\text { шт. }\end{array}$ & $\begin{array}{c}\text { маса } \\
1000 \\
\text { зерен, г }\end{array}$ \\
\hline \multicolumn{5}{|c|}{ сорт Академічний (фактор А) } \\
\hline \multirow{3}{*}{$10 . \mathrm{X}$} & Контроль & 528 & 1,11 & 37,7 \\
\cline { 2 - 5 } & Біологічний & 556 & 1,09 & 39,8 \\
\cline { 2 - 5 } & Хімічний & 579 & 1,13 & 39,4 \\
\hline \multirow{3}{*}{$20 . \mathrm{X}$} & Контроль & 537 & 1,04 & 39,8 \\
\cline { 2 - 5 } & Біологічний & 558 & 1,09 & 40,3 \\
\cline { 2 - 5 } & Хімічний & 588 & 1,11 & 41,1 \\
\hline \multirow{3}{*}{ сорт Достойний (фактор А) } & \\
\hline \multirow{3}{*}{$20 . X$} & Контроль & 533 & 1,07 & 34,1 \\
\cline { 2 - 5 } & Біологічний & 563 & 1,06 & 34,9 \\
\cline { 2 - 5 } & Хімічний & 589 & 1,05 & 37,5 \\
\hline & Контроль & 510 & 1,12 & 34,0 \\
\cline { 2 - 5 } & Біологічний & 533 & 1,11 & 34,3 \\
\cline { 2 - 5 } & Хімічний & 569 & 1,08 & 35,7 \\
\hline
\end{tabular}

Заходи захисту позитивно впливають на формування продуктивних пагонів ${ }^{8}$. Так, за рахунок заходів біологічного захисту їх кількість у середньому по досліду зросла на $4,9 \%$, а хімічного - на $10,3 \%$. При цьому спостерігалося переважно зменшення кількості зерен та маси зерна одного колосу за збільшення маси 1000 насіння на 2,6\% та 4,9\% відповідно. Урожайність зерна сорту Академічний при цьому на контролі становила $5,83 \mathrm{t} /$ га і зростала на 0,33 т/га за застосування системи біологічного захисту та на 0,77 т/га від хімічного (табл. 4).

Застосування систем захисту позитивно відображалося на зерновій продуктивності. Заходи хімічного захисту забезпечували достовірне підвищення врожайності ячменю. У середньому за роки досліджень урожайність зерна залежно від інших факторів збільшувалася на $0,42-0,89$ т/га. При цьому вищою була ефективність заходів захисту за сівби культури в оптимальні терміни. Застосування заходів біологічного захисту не завжди супроводжувалося математично достовірним підвищенням урожайності зерна, що переважно проявлялося під час

\footnotetext{
${ }^{8}$ Власюк О.С. Вплив біопрепаратів у комплексі із добривами на продуктивність та ураження хворобами ячменю ярого. Новітні технологї вирощування сільськогосподарських культур : тез доп. VI міжнар. наук. - практ. конф., м. Київ, 29 березня 2018 р. C. 64-66. URL : https://doi.org/ 10.31073/agrovisnyk201809-11.
} 
пізніх строків сівби культури. Це опосередковано є підтвердженням необхідності застосування більш складної та багаторівневої системи біологічних препаратів відповідно до особливостей умов року.

Таблиця 4

Урожайність сортів ячменю озимого залежно від строку сівби і системи захисту рослин, т/га

\begin{tabular}{|c|c|c|c|c|c|}
\hline \multirow{2}{*}{$\begin{array}{c}\text { Строки сівби } \\
\text { (фактор В) }\end{array}$} & \multirow{2}{*}{$\begin{array}{c}\text { Захист рослин } \\
\text { (фактор С) }\end{array}$} & \multicolumn{3}{|c|}{ Роки досліджень } & \multirow{2}{*}{ Середнє } \\
\hline & & 2017 & 2018 & 2019 & \\
\hline \multicolumn{6}{|c|}{ сорт Академічний (фактор А) } \\
\hline \multirow{3}{*}{ 10.X } & Контроль & 5,43 & 6,01 & 6,04 & 5,83 \\
\hline & Біологічний & 5,68 & 6,27 & 6,22 & 6,06 \\
\hline & Хімічний & 6,42 & 6,35 & 6,69 & 6,49 \\
\hline \multirow{3}{*}{ 20.X } & Контроль & 5,55 & 5,62 & 5,98 & 5,72 \\
\hline & Біологічний & 5,92 & 5,77 & 6,10 & 5,93 \\
\hline & Хімічний & 6,32 & 5,95 & 6,32 & 6,20 \\
\hline \multicolumn{6}{|c|}{ сорт Достойний } \\
\hline \multirow{3}{*}{ 10.X } & Контроль & 4,87 & 5,89 & 5,76 & 5,51 \\
\hline & Біологічний & 5,68 & 6,14 & 5,99 & 5,94 \\
\hline & Хімічний & 6,43 & 6,31 & 6,46 & 6,40 \\
\hline \multirow{3}{*}{ 20.X } & Контроль & 5,48 & 5,65 & 5,90 & 5,68 \\
\hline & Біологічний & 5,85 & 5,82 & 6,04 & 5,90 \\
\hline & Хімічний & 6,06 & 6,02 & 6,21 & 6,10 \\
\hline \multicolumn{2}{|c|}{$\begin{array}{c}\text { HIP }_{05} \text {, для часткових } \\
\text { відмінностей: А }\end{array}$} & 0,50 & 0,37 & 0,43 & \\
\hline \multicolumn{2}{|r|}{ B } & 0,61 & 0,94 & 0,38 & \\
\hline \multicolumn{2}{|r|}{$\mathrm{C}$} & 0,35 & 0,24 & 0,17 & \\
\hline
\end{tabular}

Найвищу врожайність типово озимий сорт Академічний та дворучка Достойний забезпечували під час висіву їх в оптимальні терміни за системи хімічного захисту - відповідно 6,49 та 6,4 т/га. Запровадження системи заходів із використанням біологічних препаратів зумовлює зниження врожайності зерна на 0,19 та 0,46 т/га. В окремі роки різниця між цими варіантами $є$ недостовірною

\section{3. Особливості систем захисту сої та економічна ефективність елементів біологізації під час вирощування польових культур в умовах зрошення}

Зростання в Україні площі вирощування сої закономірно спричинило погіршення фітосанітарної ситуації. Сою уражають більше п’ятдесяти 
бактеріальних, грибкових та вірусних захворювань, серед яких найбільш поширеними є фузаріоз, аскохітоз, пероноспороз, септоріоз, церкоспороз, біла гниль, антракноз, альтернаріоз, бактеріоз, бактеріальна плямистість (бактеріальний опік), бактеріальне в'янення, мозаїка. Значної шкоди посівам завдають також павутинний кліщ, акацієва огнівка, окремі види клопів та совок, тютюновий трипс, довгоносики, лучний метелик, личинки коваликів 9 .

Це зумовлює необхідність побудови системи інтегрованого захисту посівів культури на кожному етапі органогенезу. Для застосування на посівах культури дозволено понад 60 біологічних препаратів серед яких чотири - безпосередньо проти шкідників та хвороб. Правильне їх застосування дає змогу значно скоротити, а в деяких випадках повністю відмовитися від використання пестицидів ${ }^{10}$.

Дослід був побудований за двохфакторною схемою. Фактор А (сорти сої) передбачав використання ранньостиглого сорту сої Діона й середньостиглих сортів Даная та Святогор. Фактор В (система захисту рослин) передбачав наявність трьох градацій: контроль - без застосування фунгіцидів та інсектицидів (фон: протруювання насіння «Максим XL 035 FS” (1,0 л/т), інокуляція препаратом «Оптімайз в.р.» $(2,8$ л/т) і застосування грунтового гербіциду «Фронтьєр Оптіма к.е.» $(1,4$ л/га)); хімічний - фон + «Абакус» $(1,5$ л/га) $(\mathrm{BBCH} 50)$ та фунгіцид «Ретенго» (0,5 л/га) 3 інсектицидом «Белт» (0,1 л/га) (ВВСН 69); біологічний - фон + біофунгіцид «Псевдобактерін 2» $(2,0$ л/га) $(\mathrm{BBCH}$ $50)$ та біофунгіцид «Бактофіт» $(2,5$ л/га) і біоінсектицид «ЛепідоцидБТУ» $(10,0$ л/га) (ВВСН 69). Інокуляцію посівного матеріалу проводили препаратом Оптімайз у день сівби 3 витратами препарату 2,8 л/т.

Дослідження демонструють позитивний вплив застосування зазначених систем захисту на стан рослин сої. У середньому за роки спостережень більшу наземну масу формували середньостиглі сорти Даная та Святогор. Застосування елементів біологічного захисту зумовило збільшення наземної маси відносно контролю на 13,8\%, а хімічного - на $22,1 \%$. Приріст наземної маси рослин від застосування заходів захисту був вищим у середньостиглих сортів Даная та Святогор. Запровадження елементів біологічного та хімічного захисту супроводжувалося збільшенням висоти рослин відповідно на 6,5 і 5,6 см та зумовлювало більш високе кріплення нижнього бобу. Збільшення висоти рослин на варіантах захисту щодо контролю $є$ математично достовірним, однак відмінності між системами біологічного та хімічного захисту відсутні (табл. 5).

\footnotetext{
${ }^{9}$ Венедіктов О.М. Хвороби і шкідники сої та заходи боротьби з ними. Корми і кормовиробництво. 2012. Вип. 71 С. 55-61.

${ }^{10}$ Городинська М.І. Плаксюк Л.Б., Чуб А.О. Використання біопрепаратів за умов органічного виробництва сої. Вісник аграрної науки. 2018. № 9(786). С. 73-78.
} 
Таблиця 5

Біометричні показники та елементи структури врожаю сортів сої залежно від системи захисту рослин (середнє за 2017-2019 рр.)

\begin{tabular}{|l|c|c|c|c|}
\hline $\begin{array}{c}\text { Захист рослин } \\
\text { (В) }\end{array}$ & $\begin{array}{c}\text { Надземна } \\
\text { маса, г }\end{array}$ & $\begin{array}{c}\text { Висота } \\
\text { рослин, см }\end{array}$ & $\begin{array}{c}\text { Маса насіння } \\
\text { однісї } \\
\text { рослини, г }\end{array}$ & $\begin{array}{c}\text { Маса } \\
1000 \\
\text { насіння, г }\end{array}$ \\
\hline \multicolumn{5}{|c|}{ сорт Діона (фактор А) } \\
\hline Контроль & 650 & 70,7 & 5,37 & 133 \\
\hline Біологічний & 693 & 75,6 & 6,02 & 133 \\
\hline Хімічний & 748 & 72,4 & 6,52 & 133 \\
\hline \multicolumn{5}{|c|}{ сорт Даная (фактор А) } \\
\hline Контроль & 787 & 85,1 & 7,11 & 141 \\
\hline Біологічний & 916 & 94,7 & 8,17 & 143 \\
\hline Хімічний & 1026 & 93,1 & 8,30 & 141 \\
\hline \multicolumn{5}{|c|}{ сорт Святогор (фактор А) } \\
\hline Контроль & 951 & 107 & 6,65 & 136 \\
\hline Біологічний & 1108 & 112 & 7,33 & 138 \\
\hline Хімічний & 1142 & 114 & 6,92 & 134 \\
\hline
\end{tabular}

Системи захисту позитивно вплинули на окремі елементи структури врожаю. Так, у середньому кількість бобів та насіння однієї рослини на варіантах біологічного захисту була більшою на $12,3 \%$ та $11,6 \%$, а хімічного - на $23,5 \%$ та $14,1 \%$ відповідно. У результаті маса насіння 3 однієї рослини в середньому по досліду за системи біологічного захисту зросла на $12,5 \%$, а за системи хімічного захисту - на $13,7 \%$. При цьому маса 1000 шт. насіння суттєво не змінювалася. Установлено, що крупніше насіння сформували сорти Даная і Святогор, в яких у середньому маса 1000 шт. насіння відповідно становила 142 та 136 г, тоді як у сорту Діона цей показник був на рівні 133 г. За абсолютними значеннями елементи структури врожаю культури були вищими за системи хімічного захисту, однак різниця щодо системи біологічного захисту була в межах похибки досліду.

Незалежно від досліджуваних систем захисту найвищою врожайністю виділявся середньостиглий сорт Даная, який у середньому за період досліджень формував 2,93-3,35 т/га насіння, а найменшу ранньостиглий сорт Діона - 2,47-2,75 т/га (табл. 6).

Заходи біологічного захисту позитивно впливали на врожайність насіння та залежно від сорту забезпечували достовірну прибавку $0,20-0,30$ т/га. На фоні хімічного захисту врожайність окремих сортів підвищувалася на 0,28-0,43 т/га. Хоча за абсолютними значеннями врожайність сої за застосування хімічних препаратів була вищою, проте різниця з варіантами біологічного захисту була в межах похибки досліду. 
Таблиця 6

Урожайність сортів сої залежно від системи захисту рослин, т/га

\begin{tabular}{|l|c|c|c|c|c|c|}
\hline \multirow{2}{*}{ Захист рослин (В) } & \multicolumn{7}{|c|}{ Роки досліджень } & д до контролю \\
\cline { 2 - 7 } & 2017 & 2018 & 2019 & середнє & (А) & (В) \\
\hline Корт Діона (фактор А) & - \\
\hline Біологоль & 2,44 & 2,49 & 2,48 & 2,47 & - & - \\
\hline Хімічний & 2,54 & 2,73 & 2,73 & 2,67 & - & 0,20 \\
\hline \multicolumn{7}{|c|}{ сорт Даная (фактор А) } \\
\hline Контроль & 2,61 & 2,82 & 2,82 & 2,75 & - & 0,28 \\
\hline Біологічний & 2,9 & 2,79 & 3,09 & 2,93 & 0,46 & - \\
\hline Хімічний & 3,34 & 2,99 & 3,36 & 3,23 & 0,56 & 0,30 \\
\hline \multicolumn{7}{|c|}{ сорт Святогор (фактор А) } \\
\hline Контроль & 3,38 & 3,12 & 3,56 & 3,35 & 0,60 & 0,43 \\
\hline Біологічний & 2,96 & 2,62 & 2,89 & 2,82 & 0,35 & - \\
\hline Хімічний & 3,19 & 3,07 & 3,12 & 3,13 & 0,46 & 0,30 \\
\hline НІР 05 для А & 3,22 & 3,14 & 3,21 & 3,19 & 0,44 & 0,37 \\
\hline для В & 0,20 & 0,30 & 0,30 & & & \\
\hline
\end{tabular}

Ефективність досліджуваних систем захисту сої була вищою на сортах із більш тривалим періодом вегетації. Так, якщо у ранньостиглого сорту сої Діона підвищення врожайності за біологічного та хімічного захисту становило 7,96\% і $11,3 \%$, то в середньостиглих Даная та Святогор - 10,4\% i $14,6 \%$ та $10,7 \%$ i $13,0 \%$ відповідно. Найвищу врожайність отримано за застосування системи хімічного захисту середньостиглих сортів Даная - 3,35 т/га та Світогор - 3,19 т/га насіння. Застосування системи біологічного захисту забезпечувало отримання відповідно 3,23 та 3,13 т/га.

Як свідчить виробничий досвід, за використання належної системи економічна ефективність вирощування сільськогосподарських культур значно підвищується. У результаті проведених досліджень установлено, що ступінь економічної ефективності вирощування культур формувався залежно від величини отриманого основного та додаткового врожаю i цінової ситуації на рослинницьку продукцію та витратні матеріали. Важливими перевагами біологічних препаратів $\epsilon$ вартість обробки одиниці площі та пролонгована їх дія як об’єктів живої природи, позитивні екологічні наслідки.

В умовах Півдня України сою вирощують виключно в умовах зрошення, що потребує значної кількості води. Зважаючи на високі меліоративні витрати, перевагою $є$ позитивний вплив на ефективність використання вологи. Оскільки формування більшого врожаю супроводжується зростання витрат вологи, закономірним є збільшення 
сумарного водоспоживання, яке становило у середньостиглих сортів Даная $5737 \mathrm{~m}^{3} /$ га та Святогор $5823 \mathrm{~m}^{3} /$ га порівняно 3 ранньостиглим сортом Діона $5158 \mathrm{~m}^{3} /$ га. Досліджувані системи захисту, позитивно впливаючи на формування біологічної маси, також зумовлювали зростання сумарного водоспоживання, однак ефективність використання вологи зростала. За системи біологічного захисту коефіцієнт водоспоживання зменшувався на 7,2-10,9\%, а хімічного - на 11,0-13,0\%. Зважаючи на велику вартість поливної води, це забезпечує вагомі економічні переваги.

Біологізація системи захисту посівів сої зумовлює зменшення виробничих витрат порівняно із системою хімічного захисту (рис. 2).

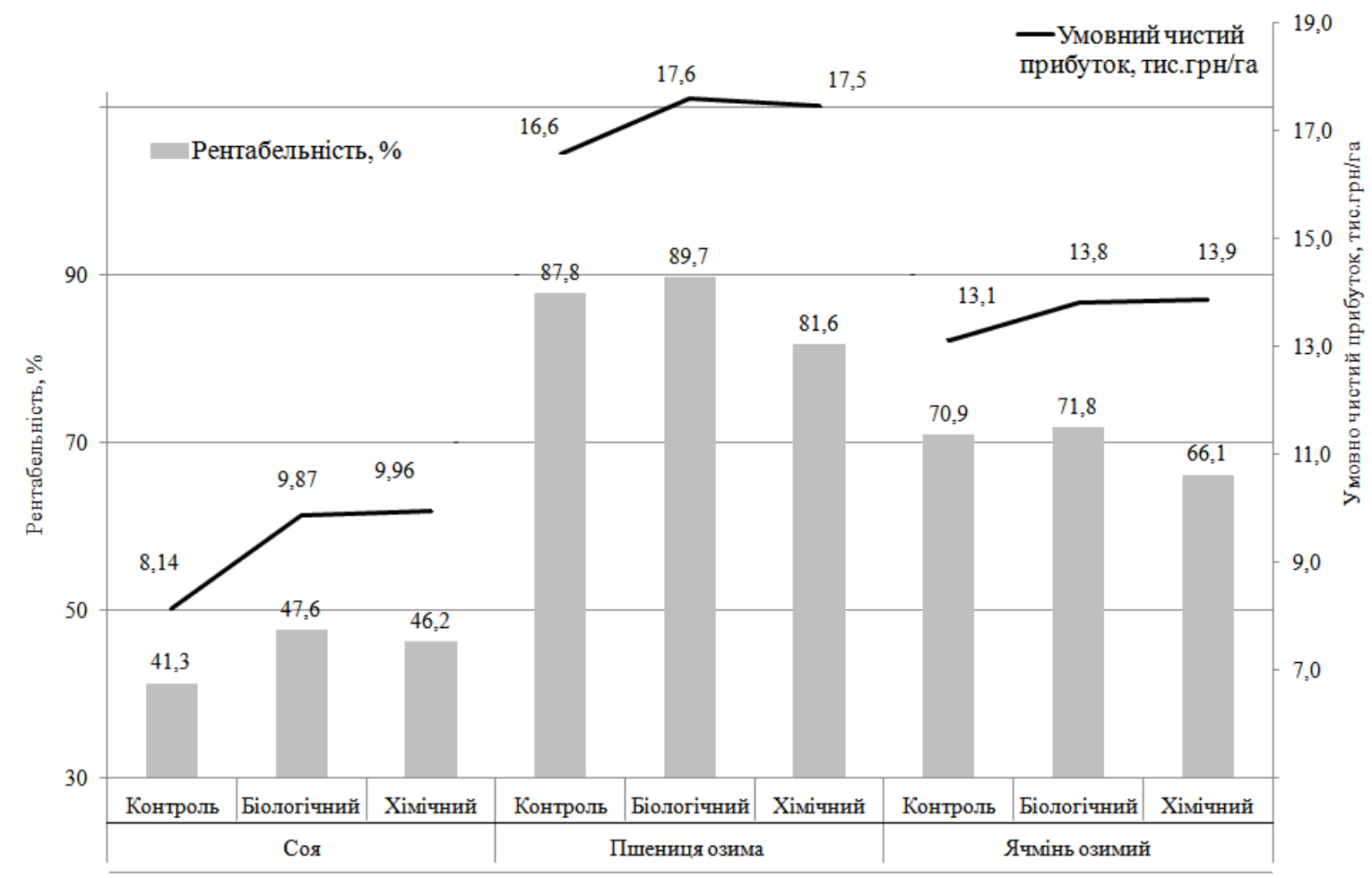

Рис. 2. Економічна ефективність систем захисту польових культур від шкідників та хвороб

3 урахуванням потреб на збирання додаткової продукції витрати зростають у середньому на 1 тис грн/га, тоді як за системи хімічного захисту - на 1,8 тис грн/га. При цьому встановлено зменшення собівартості насіння на 220-360 грн/т та підвищення рентабельності вирощування культури на 3,8-7,8\%. За системи хімічного захисту собівартість насіння зменшувалася на 130-320 грн/т, а рентабельність зростала на 2,0-7,3\%. Економічні переваги та екологічний ефект указують на перспективу застосування біофунгіцидів «Псевдобактерін 2» 
i «Бактофіт» та біоінсектициду «Лепідоцид-БТУ» для захисту посівів сої від шкідливих організмів.

Проведення додаткових заходів для захисту посівів пшениці озимої біологічними та хімічними препаратами зумовлювало збільшення прямих та опосередкованих виробничих витрат відповідно на 758 та 2509 грн/га порівняно з варіантом без захисту. Однак це призводило до зростання умовного чистого прибутку у середньому на 1044 та 888 грн/га. Унаслідок собівартість зерна зменшувалася залежно від інших факторів із 2,69-3,22 тис грн/т на контролі до 2,66-3,12 тис грн/т за системи біологічного захисту.

На фоні заходів хімічного захисту собівартість зерна була в межах 2,79-3,22 тис грн/т. Найвищу рентабельність $105 \%$ та прибуток 20,7 тис грн/га забезпечувала сівба сорту пшениці озимої Анатолія в оптимальні терміни (20 вересня) за системи біологічного захисту посівів. За системи хімічного захисту умовно чистий прибуток становив 20,4 тис грн/га, а рентабельність - 95,4\%.

Щодо пшениці озимої обробка посівів ячменю озимого біологічними препаратами потребувала менших виробничих витрат, що в середньому становило 1,71 тис грн/га. Проте умовний чистий прибуток був вищим на варіантах хімічного захисту - 12,8-14,9 тис грн/га порівняно 3 біологічним - 13,1-14,5 тис грн/га та контролем - 12,0-13,9 тис грн/га. Однак вищою $є$ рентабельність за застосування системи біологічного захисту посівів.

Зважаючи на коливання погодних умов осіннього періоду, за оптимальних термінів посіву більший умовний прибуток - 14,9 тис грн/га 3 рентабельністю $71,0 \%$ забезпечує вирощування сорту ячменю озимого Академічний за системи хімічного захисту. Застосування біологічних препаратів супроводжується зменшенням прибутку до 14,5 тис грн/га, однак збільшенням рентабельності до $75,1 \%$.

За сівби у пізні терміни (20 жовтня) вищий умовний прибуток 13,5 тис грн/га з рентабельністю 70,1\% забезпечує використання сорту ячменю озимого-дворучки Достойний за застосування системи біологічного захисту.

\section{ВИСНОВКИ}

Застосування на посівах пшениці, ячменю озимого та сої біологічних препаратів «Псевдобактерін 2», «Бактофіт», «Бітоксибацилін-БТУ», «Лепідоцид-БТУ» поліпшує фітосанітарний стан агроценозу, сприяє формуванню та розвитку генеративних органів, що позитивно впливає на врожайність культур. За технічною ефективністю біологічні препарати поступаються хімічним. Запровадження елементів біологізації в систему захисту посівів пшениці, ячменю та сої призводить до деякого зменшення 
врожайності за поліпшення окремих показників економічної ефективності виробництва. Аналіз екологічної ефективності застосування різних систем захисту в посівах сільськогосподарських культур показав, що доцільність їх застосування визначалася, насамперед, біологічною ефективністю проти шкідників та хвороб, величиною додатково одержаної продукції та зменшенням пестицидного навантаження на меліоративні агроценози. Активне впровадження у виробництво нових ефективних систем захисту сільськогосподарських культур із використанням мікробіологічних препаратів сприяє отриманню екологічно безпечної рослинницької продукції, оздоровленню навколишнього середовища та $є$ новим, більш високим рівнем розвитку сучасного аграрного виробництва.

\section{АНОТАЦІЯ}

Наведено результати польових досліджень ефективності застосування біологічних препаратів у системі захисту пшениці озимої, ячменю озимого та сої в меліоративних агрофітоценозах Півдня України. Оцінюється велике значення окремих біологічних фунгіцидів та інсектицидів як альтернативних засобів захисту рослин від шкідників та хвороб у системі інтенсивних агротехнологій. Установлено, що застосування на посівах пшениці та ячменю озимого «Псевдобактеріну 2» $(1,0$ л/га) перед трубкуванням та «Бактофіту» (3 л/га) + біоінсектициду «Бітоксибацилін БТУ» (10 л/га) на початку колосіння на фоні протруювання насіння «Кінто Дуо» $(2,0$ л/т) та застосування гербіциду «Гроділ Максі» $(0,11$ л/га) поліпшує фітосанітарний стан посівів, підвищує врожайність відповідно на 4,0-7,1\% та 3,7-7,8\%. Застосування на посівах сої біофунгіциду «Псевдобактерін 2» $(2,0$ л/га) на початку цвітіння та біофунгіциду «Бактофіт» $(2,5 \pi /$ га) і біоінсектициду «Лепідоцид-БТУ» $(10,0$ л/га) на початку формування бобів на фоні протруювання насіння «Максим XL 035 FS» $(1,0$ л/т) інокуляції препаратом «Оптімайз в.р.» $(2,8$ л/т) і застосування грунтового гербіциду «Фронтьєр Оптіма к.е.» (1,4 л/га) позитивно впливає на елементи структури та забезпечує підвищення врожайності насіння на $8,0-10,7 \%$. Установлено, що за використання в технології вирощування пшениці озимої, ячменю озимого та сої біологічних препаратів як елементів інтегрованого захисту проявляється тенденція до зниження врожайності за поліпшення окремих показників економічної ефективності виробництва. Установлено вищу технічну ефективність хімічних препаратів порівняно з біоінсектицидами, що потребує розширення їх переліку та вдосконалення системи застосування. Зазначено, що перспективним $є$ розроблення та випробування біологічних препаратів і систематичності їх застосування за вирощування польових культур для 
підвищення врожайності та якості продукції й оздоровлення меліоративних агрофітоценозів.

\section{ЛІТЕРАТУРА}

1. Писаренко В.М. Захист рослин: екологічно обгрунтовані системи : підручник. Полтава : Камелот, 2000. 188 с.

2. Корнійчук М.С. Захист польових культур від шкідників і хвороб за технологій органічного виробництва. Збірник наукових пращь Національного наукового иентру «Інститут землеробства НААН». 2014. Вип. 1-2. С. 98-110. URL : http://nbuv.gov.ua/UJRN/znpzeml_2014_ 1-2 17.

3. Бровдій В.М. Біологічний захист рослин : навчальний посібник. Київ : Світ, 2004. 352 с.

4. Василенко Л. Удосконалення державної політики у сфері обігу пестицидів. Економічний дискурс. 2018. Вип. 2. С. 25-31. DOI : 10.36742/2410-0919.

5. Вожегова А.А., Кривенко А.І. Вплив біопрепаратів на продуктивність пшениці озимої та економічно-енергетичну ефективність технології ï вирощування в умовах Півдня України. Вісник аграрної науки Причорномор’я. 2019. № 1. С. 39-46. DOI : 10.31521/2313092X/2019-1(101)-6.

6. Буцяк А.А. Мікроорганізми як альтернатива пестицидам у виробництві екологічно безпечної продукції рослинництва. Науковий вісник Львівського наиіонального університету ветеринарної медиџини та біотехнологій ім. Гжиџького. 2013. Т. 15. № 1(4). С. 30-34. URL : http://nbuv.gov.ua/UJRN/nvlnu_2013_15_1(4)_8.

7. Антипова Л.К. Шкідливі об'єкти в посівах пшениці озимої. Вісник аграрної науки Причорномор'я. 2013 Т. 1. Вип. 4. С. 95-102. DOI : 10.31521/2313-092X.

8. Власюк О.С. Вплив біопрепаратів у комплексі з добривами на продуктивність та ураження хворобами ячменю ярого. Новітні технології вирощування сільськогосподарських культур : тез. доп. VI міжнар. наук. - практ. конф., м. Київ, 29 березня 2018 р. С. 64-66. URL : https://doi.org/10.31073/agrovisnyk201809-11.

9. Венедіктов О.М. Хвороби і шкідники сої та заходи боротьби з ними. Корми і кормовиробництво. 2012. Вип. 71. С. 55-61.

10. Городинська M.I., Плаксюк Л.Б., Чуб А.О. Використання біопрепаратів за умов органічного виробництва сої. Вісник аграрної науки. 2018. № 9(786). С. 73-78. 


\section{Information about authors:}

Zaiets S. O.,

Candidate of Agricultural Sciences, Senior Researcher, Head of the Department of Crop Production and Non-Irrigated Agriculture Institute of Irrigated Agriculture of the National Academy of Agrarian Sciences of Ukraine Naddnipryanske sett., Kherson, 73483, Ukraine

Rudik O. L., Doctor of Agricultural Sciences, Associate Professor at the Department of Agriculture Kherson State Agricultural University 23, Stritsenska str., Kherson, 73006, Ukraine 